\title{
Az ELTE Egyetemi Könyvtár ősnyomtatványtára
}

\section{Az ősnyomtatvány kifejezés eredete, használata}

A latin ,incunabulum” kifejezést egy német filológus, Bernhard Mallinckrodt (Mallinkrot, 1591-1664) használta elöször az 1640-ben Kölnben (typ. Kinchius) megjelent, De ortu ac progressu artis typographicae dissertatio historica címü munkájában. ${ }^{1}$ A megjelöléssel a legkorábbi, 1500 vége előtt készült nyomdatermékeket illette. Ösnyomtatvány az a könyv vagy egyleveles kiadvány, amelyet az európai könyvnyomtatás feltalálása óta, azaz az 1450-es évek közepétől a XV. század végéig, pontosabban 1500. december 31-ig mozgatható betükkel, szedéssel-nyomással állítottak elő. Nem számítanak ősnyomtatványnak az úgynevezett táblanyomatok, valamint a Kínában, Koreában és általában a Távol-Keleten ebben az időszakban sokszorosított munkák. Az 1500. december 31-i könyvészeti korszakhatár hosszú ideig vitatott volt, ugyanis egyrészt a kisebb, Alpoktól északra müködő nyomdákból még 1520-1530 körül is kerültek ki olyan nyomtatványok, melyek tipográfiája ötven évvel korábbi sajátosságokat hordozott. Másrészt a velencei nyomtatványok már 1490 körül úgy készültek, mint a XVI. századi kiadványok, volt címlapjuk, levél- vagy lapszámozásuk, aránylag kevés rövidítéssel éltek és az előállításukhoz a korábban használt betűtípusoktól eltérően, jól olvasható antikva betütípust használták. ${ }^{2}$

Gutenberg és első követői a gót misekönyvek betüit vették alapul a betűmetszéshez. Később, 1464-ben a strassburgi Adolf Rusch egy másik, a kódexekben kedvelt betütípust választott a metszett betük készítéséhez, az antikvát. A két betütípus hamarosan az ősnyomtatványok tartalmához igazodott: gót betükkel általában a liturgikus és bibliai szövegeket nyomtatták ki, az antikvát pedig a klasszikus latin szövegekhez használták fel.

\footnotetext{
${ }^{1}$ A kötetből az ELTE Egyetemi Könyvtár nem őriz példányt, Magyarországon az Országos Széchényi Könyvtárban található meg a nyomtatvány a 302.718 jelzeten.

${ }^{2}$ E különbségek vezettek oda, hogy például a lipcsei Egyetemi Könyvtár incunabulumkatalógusa sokáig az itáliai ősnyomtatványokat csak 1480-ig tartotta számon. Más ősnyomtatvány-katalógusok ugyanakkor a reformáció évével, 1520-szal vagy 1550-nel zárták le az ősnyomtatványok korát. Magyarországon például Récsey Viktor a pannonhalmi régi nyomtatványok katalógusa készítése kapcsán az 1536-os évet tekintette korszakhatárnak.
} 


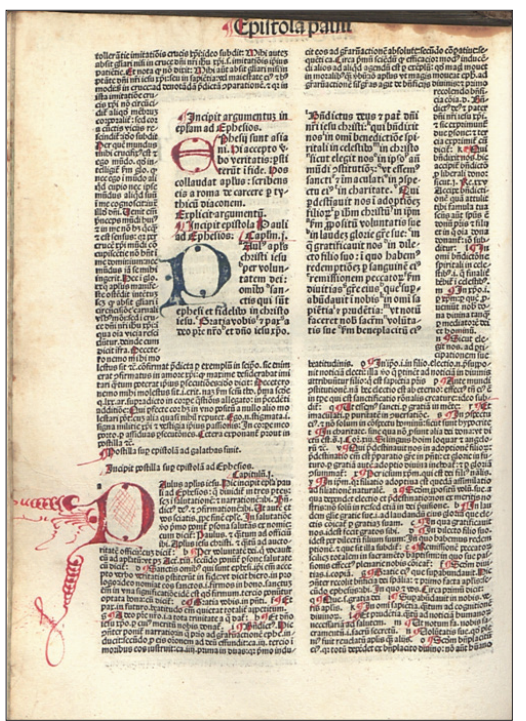

1. kép. Gót betüs ősnyomtatvány Biblia, Nürnberg, 1485, 235v Inc 278

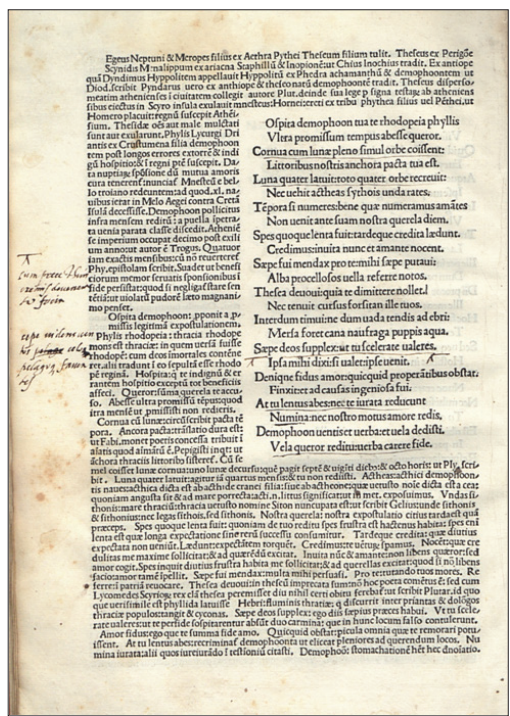

2. kép. Antikvával készült ősnyomtatvány. Publius Ovidius Naso, Epistolae heroides, Velenzia, 1482, 4v Inc 128

Az ősnyomtatványok világszerte a legdrágább dokumentumok közé tartoznak. ${ }^{3}$ Különleges értéküket nem elsősorban a tartalmuk határozza meg, közrejátszik benne a nyomdászattörténeti jelentőség, a régiség és az egyedivé tett állapot.

\footnotetext{
${ }^{3}$ http://www.forumrarebooks.com/index.html?nav_id=1 (2015. november).
} 


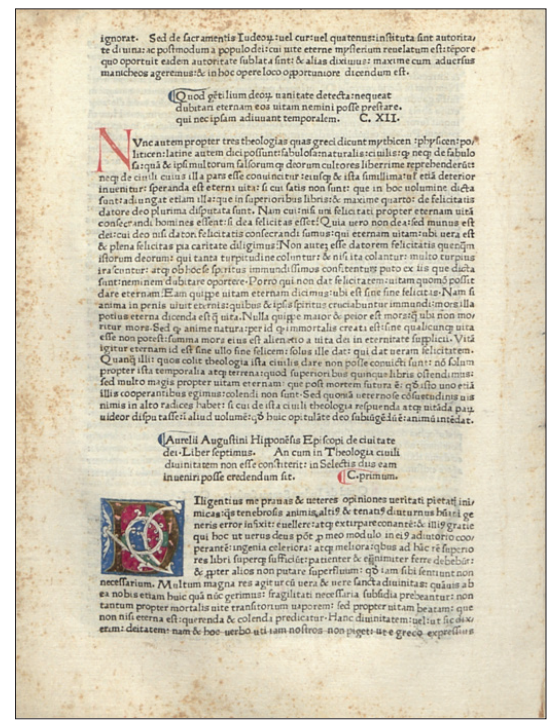

3. kép. Szent Ágoston, De civitate Dei, Roma, 1474, Inc 16

A legértékesebbek a könyvnyomtatás feltalálásához időben közelebb álló munkák. ${ }^{4}$ A XV. századi ösnyomdákból becslések szerint mintegy 35.000 mü közel 500.000 példányban került ki. E becses nyomtatványok többi nyomdaterméktől elkülönített gyüjteményi kezelése a XVII. századtól követhető nyomon.

\section{A legkorábbi ősnyomtatványok könyvészeti sajátosságai}

A XV. század második felének nyomdászai tudatosan törekedtek arra, hogy munkáik hasonlítsanak a középkori kézzel írott könyvekhez, a kódexekhez. Ennek érdekében a kódex-írás főbb betütípusain (gót, antikva) kívül az ősnyomdászok átvették a kódexekben használt rövidítéseket (abbreviatura) is, s ezek használatával biztosították a sorok azonos hosszúságát. A mintegy hatvan-nyolcvan általánosan használt rövidítés mellett kedveltek voltak a ligatúrák (közös matricára öntött kettős betűk) is. ${ }^{5} \mathrm{Az}$ egyes kiadások példányszáma eleinte alacsony volt.

${ }^{4}$ Kiemelkedően értékesek mindazok az ősnyomtatványok, melyek egy-egy település vagy műhely első termékei közé tartoznak, továbbá az úgynevezett ritka, kis számban készült vagy fennmaradt kiadványok. A ritka kiadványok közül kiemelkednek mindazok az ősnyomtatványok, amelyek mindössze egyetlen ismert példányban maradtak fenn (unikum példányok). Különösen értékesek továbbá a pergamenre nyomott, a középkori minta szerint kézzel díszített és az antik auktorok múveit tartalmazó kötetek.

${ }^{5}$ További középkori „örökség” volt a széles margó, ami fennmaradt az „ösnyomdászok” első generációi körében is; vagy ők, vagy a kötetek megvásárlói anyagi lehetőségeik függvényében díszíttethették és köttethették be a megvásárolt, sok esetben hajtogatás elötti (krúda) nyomtatott „könyveket”. Mindez azt jelenti, hogy az ősnyomtatványokon - éppúgy, mint a kódexeken - általában különböző, minimálisan két személy dolgozott: a nyomdász és a kötet díszítéseit készítő 
A példányszámok emelkedését elsősorban az ösztönözte, hogy egy-egy kötet teljes elöállítási ára körülbelül egyharmada volt a korábbi kéziratos kódexekének. Címlapja, jobban mondva címlap-őse eleinte még nem volt az ősnyomtatványoknak. Az első „címlap”-pal rendelkező ősnyomtatványt Velencében készítették Nicolas Jenson nyomdájában (1485), nagyon rövid szöveget, a címet és a szerző nevét tartalmazta. ${ }^{6} \mathrm{Az}$ ösnyomtatványok - eltérően a mai nyomtatványoktól olyan ívfüzetekből állnak, melyeknél az íveket egymásba helyezték. ${ }^{7}$ Nehéz és fáradságos munkafolyamat a kelendőbb müvek újabb kiadásainak elkülönítése. Nem ritkák az ugyanazon kiadásokon belüli variánsok sem - ezek általában úgy keletkeztek, hogy a nyomás alatt egyúttal korrigálást is végeztek. Ha például egy ívből már kinyomtak száz példányt és ekkor fedezték fel a hibát, egyszerüen korrigálták, s így ugyanazon ív további példányai már részben eltértek az előbbiektől. Az ősnyomtatványok sajátos könyvészeti megjelenése miatt feldolgozásuk körültekintő figyelmet kíván. ${ }^{8}$ A katalogizálás során érdemes tudományos kuta-

miniátor. Néhány évtizeddel a könyvnyomtatás feltalálása után a nyomdászok igyekeztek azzal „kiváltani" az illuminátorok munkáját, hogy fametszetes keretdíszt és iniciálét nyomtattak a kötetek első, kezdő fóliójának rectó oldalára, amit kézzel tovább lehetett díszíteni festéssel vagy rajzolással. A díszítés további lehetősége volt az úgynevezett rubrumozás (a bekezdések, illetve a mondatok kezdőbetűinek jelzése piros tintás áthúzással). Ezáltal - a kódexekhez hasonlóan - egy-egy ősnyomtatvány-kiadás akár minden egyes példánya teljesen egyedivé válhatott. A kötetek e díszek, továbbá a kézmüves gótikus és/vagy reneszánsz bőrkötések, azaz egyedi jellegzetességeik révén különböznek egymástól - bár ugyanabból a nyomdából kikerült, ugyanazon kiadású művek voltak.

${ }^{6} \mathrm{~A}$ többi megjelenéssel kapcsolatos adatsor (szerző, cím, nyomdász, megrendelő, nyomtatási hely és idő) a nyomtatványok végére, az úgynevezett kolofonba került elhelyezésre. Az ősnyomtatványok azonosítását jelentősen megnehezíti az a tény, hogy mintegy egyharmadukból hiányzik a kolofon.

${ }^{7}$ A kézi sajtó korában később a hajtogatott íveket ettől eltérően folyamatosan egymás mellé helyezték. Az ősnyomtatványoknak általában nincs lapszámozásuk, az ívfüzeteket viszont jelzésekkel látták el; legáltalánosabban az abc betűivel. A leveleket az ívfüzet közepéig római számokkal jelölték. A levelek és az ívek sorrendjét a lap alján őrszó (custos) jelezte. A nyomtatványok legtöbbjének végén úgynevezett registrum található, amely útmutatót jelent az ívfüzetek sorrendjére vonatkozóan. A registrum terjedelme idővel lerövidült, végső változatában már csupán az ívfüzetek terjedelmét közölték benne (például: „omnes sunt quaterni, praeter c, e, f, g, qui sunt quinterni”). Egyes területeken az ilyen jellegü registrum nem terjedt el, helyette - például a német nyelvterületen - a tartalomjegyzéket vagy a névmutatót nevezték registrumnak.

${ }^{8}$ Címleírásuk teljesen eltér a „modern” könyvekétől: egy-egy ősnyomtatványról általában kétféle címleírás készül, egy rövid és egy teljes, az előbbinél jelentősen hosszabb. A teljes címleírás tartalmazza a szerző nevét, általában középkori formában, elöl a keresztnévvel. A szerzős ősnyomtatványok jelentős részében nem tüntették fel a szerző nevét, ezt gondos odafigyeléssel és utánakereséssel lehet és kell megállapítani. A címek lehetnek rövidek vagy néha bőbeszédủen hosszúak. A felvétel során ezért az irodalomtörténetileg elfogadott cím-alak a mértékadó, mindenféle zárójel alkalmazása nélkül. Ez az alak esetenként egybeesik, azonos a köteten megtalálható címmel. Az impresszumadatok megszokott sorrendje (hely, nyomdász, év), esetenként kiegészül a kiadó nevével (a „pro" és az „impensis” megjelöléssel együtt). A terjedelem levélszámozással adható meg, melyet kiegészíthet a kollacionálás. A teljes leírás második részében betúhíven kell visszaadni a nyomtatvány címlapját, továbbá a nyomtatást tartalmazó első lapnak és a tulajdonképpeni szövegnek az első sorait, a második ívfüzet első sorát, valamint a kolofont. Minden esetben jelezni kell a példány csonkaságát, kézira- 
tói szempontokat is érvényesíteni. Így elsősorban fontosnak tünik megkeresni és rendszerezni mindazokat az ,iratokat”, melyekben a konkrét müről érdemleges módon szó esik - például hasznos megvizsgálni a kötet használatát, eladásátmegvételét, ajándékozását és hagyományozását. ${ }^{9}$

\section{A legkorábbi Magyarországon készült ősnyomtatványok}

Jelenlegi ismereteink szerint nincs teljes terjedelmében magyar nyelvü ösnyomtatvány. A XVIII. század végén Bartalis Antal jegenyei plébános ugyan birtokolni vélt egy 1484-ben Nürnbergben kiadott magyar nyelvü nyomtatott éneket oratióval együtt Szent István király jobb kezéről, s ezt a Régi Magyarországi Nyomtatványok $(R M N y)$ első kötete - Szabó Károly hungaricum bibliográfiája első kötetét követve - függelékben (App. 4) közli is, de a bibliográfia - ugyanitt - a „nyomtatványra” vonatkozó szakirodalmat kronologikusan áttekintve, ezt a tételt „tévesen feltételezett"-nek minősítette. ${ }^{10}$ Az első Magyarországon kinyomtatott könyv latin

tos bejegyzéseit, díszítését és kötését. A megjegyzésben érdemes feltüntetni a müre vonatkozó fontosabb irodalmat is. Az ösnyomtatványokat több, általában három-négy mértékadó ősnyomtatvány bibliográfiában szükséges behasonlítani. A kolofon nélküli ösnyomtatványok (az ösnyomtatványok mintegy egyharmad része) azonosításakor az egyes ősnyomdászokra jellemző betüfajták elkülönítése jelentheti a segítséget. Erre vonatkozóan Konrad Haebler (elődei, Henri Brodshaw és Robert Proctor munkáját felhasználva) megnyugtató tudományos módszert dolgozott ki. A legváltozatosabban metszett gót betüt, az 'M'-et alapul véve típusrepertóriumot dolgozott ki, s az 'M' 101 alapformáját különítette el. Ezt kiegészítette a sorok nagyságával, húsz sor méretét alapul véve. A kolofon nélküli ösnyomtatványok esetében először az 'M' betüt kell meghatározni, majd lemérni a húsz sor távolságát és a két adatot be kell hasonlítani a típusrepertóriumban. A vizsgálatot érdemes kiegészíteni az így meghatározott nyomdász egy másik ismert és már biztosan azonosított müvével történő összevetéssel. A nem gót betűs, kolofon nélküli ősnyomtatványok azonosítása az előbbinél nehezebb feladat, mivel az antikva betúknél sokkal kevesebb az egymástól való eltérés. Itt kiindulópontként a 'Qu' betü szolgál. Az így létre hozott antikva-repertórium a különleges formákkal együtt összesen húsz 'Qu' formát különít el, s ehhez megadja a 'h', az 'y' és néhány különleges, a nyomtatásban alkalmazott jel sajátosságát. A típus-meghatározás alapján következtetést lehet levonni a nyomtatvány keletkezési idejére is. Ez a módszer általában pontos eredményeket biztosít 1480 körülig. Később, mivel az egyes ősnyomda-mühelyek megvásárolták egymás betükészletét, azokat többnyire átöntötték, s ennek következtében a sorméretek általában néhány milliméterrel megváltoztak, nehezebb a meghatározás. A lehetőség szerinti minél nagyobb pontosságra törekedve érdemes a vizsgálatot a vízjelek figyelembevételével és a nyomdák egyéb kiadványaival történő összevetésekkel kombinálni.

${ }^{9}$ Az így elökerült források segítséget nyújtanak a könyvtörténeti sajátosságok megfogalmazására, melyek kiterjedhetnek a kor írásbeliségére, a könyvek kiadására és forgalmazására, iskola- és művelődéstörténeti következtetések levonására. Ezek a szempontok - következetesen érvényesítve - összekapcsolhatók más jellegü kutatásokkal, s segítségükkel lehetőség nyílik az ősnyomdászat korának eruditív mủveltségére, az európai szellemi áramlatok kölcsönhatására vonatkozó újabb és újabb megfigyelések megfogalmazására.

${ }^{10}$ Ismételten áttanulmányozva az e „cantilená”-ra vonatkozó kibővített, jelenleg hozzáférhető teljes forrásanyagot, megállapíthatóvá vált, hogy a jegenyei plébános tulajdonában nem egy 1484-ben megjelent ritka nyomtatvány volt, hanem néhány füzet a Szentjobb ereklyéről nagy példányszámban 1771-ben megjelent füzetes kiadványokból. Bartalis a XVIII. század végi általánosan divatos szövegarchaizálásokhoz hasonlóan megtévesztő módon archaizálta egy ilyen füzet 
nyelvü. Ez a Chronica Hungarorum (GW 6686), amelyet - jelenlegi ismereteink szerint - egy Rómából Magyarországra hívott német nyomdász (akinek személye ma is ismeretlen), Andreas Hess nyomtatott 1473-ban. ${ }^{11}$

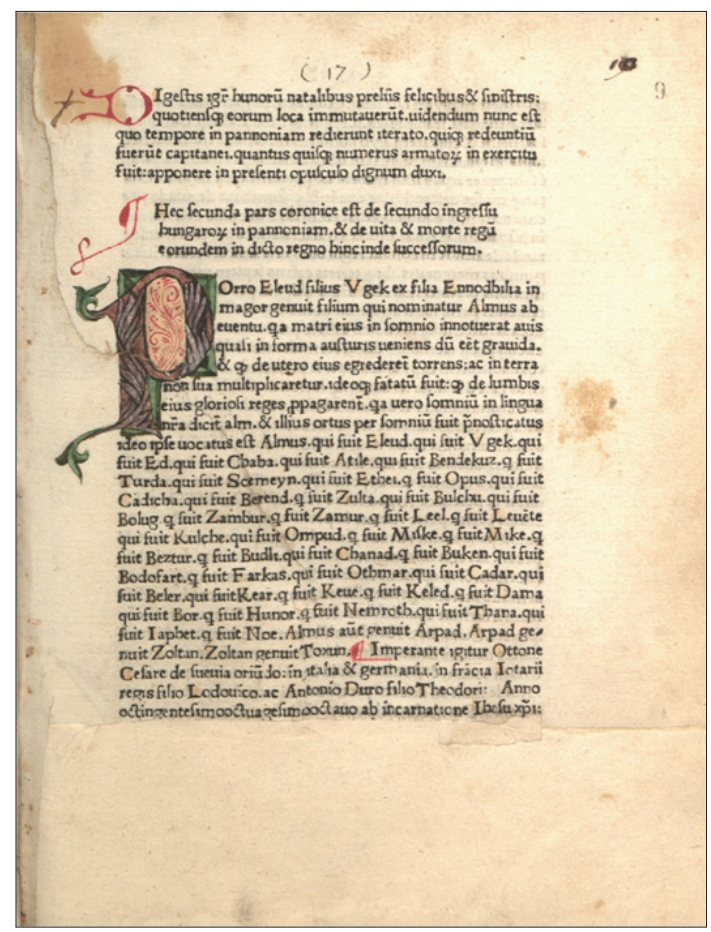

4. kép. Chronica Ungarorum, Buda, Andreas Hess, 1473, 9r

néhány sorát, s ezzel igyekezett egy újabb régi magyar nyelvemléket „létrehozni”, azaz koholni. Vö. Knapp Éva: Egy tévesen feltételezett 1484-es magyar nyelvü nyomtatvány eszmetörténeti kapcsolatai a XVIII. század végén. = Uö., Libellus. Válogatott könyv-és könyvtártörténeti tanulmányok, Budapest, Balassi Kiadó, 2007. 247-272.

${ }^{11}$ A címlap nélküli, Andreas Hess ajánlásával kezdődő („Ad [...] Ladislaum, praepositum ecclesiae Budensis, prothonotarium apostolicum, necnon vicecancellarium [...] regis Matthiae") kiadvány Magyarország történetét tartalmazza. Egyrészt a XIV. században szerkesztett magyar krónika egy változatát, másrészt ennek kibővítését a nyomtatás idejéig történt eseményekkel. Két fö részből áll, az első huszonnégy fejezetben a hunok történetét, a második kettőszáznegyvenhat fejezetben a magyarok történetét beszéli el, mindegyik elején tartalomra utaló cím olvasható. A Budán, 1473 pünkösdjén Hess Andrást sajtója alól kikerült első Magyarországon nyomtatott könyvvel a magyar ősnyomdászat több országot is megelőzött, mert például Skandináviában vagy Angliában ennél később indultak az első ősnyomdák. A Hess-nyomda valószínűleg az azon a helyen álló egykori épületben müködött, ahol ma a budai várban tér örzi a nevét. A Chronica Hungarorumból jelenleg összesen tíz példány ismert, ezek közül mindössze kettőt őriz magyarországi közgyüjtemény, egyet az Országos Széchényi Könyvtár, egy másikat a budapesti Egyetemi Könyvtár (ELTE Egyetemi Könyvtár). A nemzetközi ősnyomtatvány irodalomban Michael Maittaire tett először 1733ban említést a nyomtatványról az Annales typographici (IV, Amsterdam, 331) címü munkájában. 
A Hess-nyomda egy másik budai terméke is fennmaradt 1473-ból (Leonardi Aretini in opusculum Magni Basilii de legendis poeticis incipit feliciter, GW 3702) ennek megjelenése után azonban a tipográfia valószínúleg beszüntette tevékenységét. ${ }^{12}$

A második magyar ősnyomda 1477-1480 között múködött. Jelenleg négy itt készült nyomtatványt tart számon a szakirodalom (RMNy 3, 4, 5, 6). A nyomdáról még ma sincs semmiféle bővebb ismeret, elnevezése az egyik fennmaradt, itt készült mü címéből Typographia Confessionalis. ${ }^{13}$ Itt készült Laudivius Szent Jeromos életrajza is, melyből a világon jelenleg kizárólag a budapesti Egyetemi Könyvtár öriz példányt. ${ }^{14}$

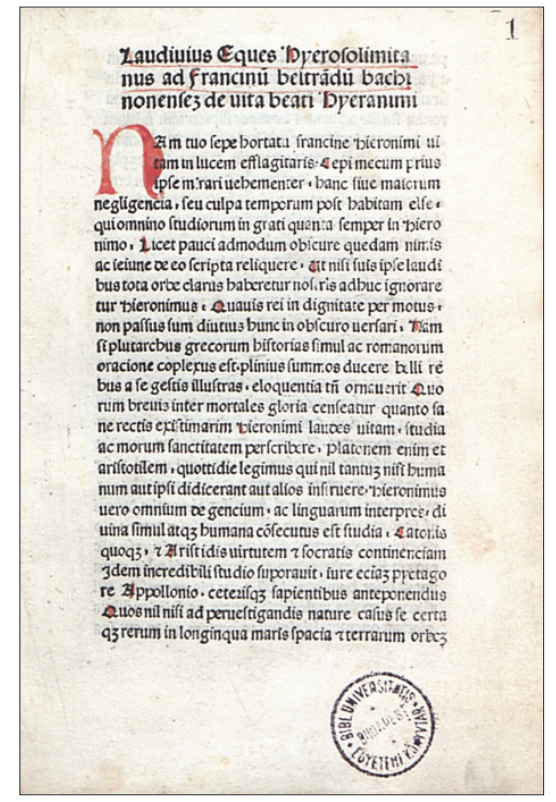

5. kép. Laudivius Zacchia, Vezzanensis, Vita beati Hieronymi, [In Hungaria, Typographia Confessionalis, 1477-1480?], 1r Inc 862

${ }^{12}$ Ez a címlap nélküli, negyedrét alakú, húsz levél terjedelmủ munka erkölcsbölcseleti értekezéseket tartalmaz. A nyomtatványban Basilius Magnus A fiatalokhoz címü müvének latin fordítása és Xenophon Szókratész védőbeszéde (szintén latin nyelven) olvasható. A szakirodalom ezt a munkát tartotta hosszú ideig az első magyarországi ősnyomtatványnak, Fitz József azonban a Chronica Hungarorum előszavából megállapította, hogy a krónika volt valójában az első magyar földön kinyomtatott mü (Fitz József, Hess András, a budai ösnyomdász, Budapest, 1932. 132.).

${ }^{13}$ A nyomda müködéséhez kapcsolódik egy gyóntatói kézikönyv (Antoninus Florentinus, Confessionale GW 2108, RMNy 3), egy egykorú adat alapján feltételezhető német nyelvü politikai röpirat (RMNy 4).

${ }^{14}$ További nyomtatványok e műhelyből: és egy, Johannes Han pozsonyi plébános nevének (aki a török elleni háború támogatására hirdetett búcsú egyik biztosa volt) feltüntetésével búcsú engedélyezését igazoló nyomtatvány, egy búcsúlevél ürlap (egyetlen példányát Pozsonyban - Vedecká knižnica mesta Bratislavy - őrzik, RMNy 6). 


\section{Ősnyomtatványok a budapesti Egyetemi Könyvtárban - (ELTE Egyetemi Könyvtár) különös tekintettel országos unikum példányokra}

A könyvtár jogelödje, az első nagyszombati jezsuita könyvtár megalapításával (1561) és e könyvtár jogutódai révén jött létre az az országban egyedülálló ősnyomtatvány-gyüjtemény, mely évszázadokon át egészen a mai napig együtt maradt és folyamatosan bővült. A tár kiemelkedő jelentőségű abból a szempontból is, hogy állományát nem magángyüjtemény formájában, látványosságként gyüjtötték össze, hanem napi használatra, elsősorban oktatásra és tanulásra szánták. Fő jellegzetessége, hogy az eredeti állományt évszázadokon keresztül megőrizte a gyüjtemény. Ezt az állítást elsősorban a kötetekben megtalálható viszonylag sok bejegyzés, marginália bizonyítja. A tár történetére vonatkozó két fó forrás a kötetekben található egykori tulajdonosi bejegyzéseken kívül a könyvtár fennmaradt XVII. századi történeti katalógusai. A legrégebbi ősnyomtatvány-beszerzések az 1561 utáni évekből származnak. ${ }^{15}$ A gyüjteményt bővítő egyik nevezetes ősnyomtatványban, Thuróczi, Chronica Hungarorumában a következő bejegyzés olvasható: „donatus a Francisco Zabo 1590” - „Inscriptus Collegij Turociensis Societatis Jesu”.

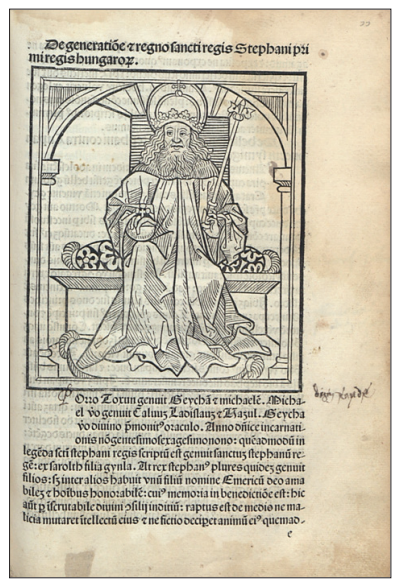

6. kép. Thuróczy János, Chronica Hungarorum, Brno, Konrad Stahel et Matthias Preinlein, 1488; Inc. 338

${ }^{15}$ Az ősnyomtatványok száma a könyvtár történetének kezdetétől folyamatosan gyarapodott. Dümmerth Dezső kutatási eredményét elfogadva, mai ismereteink szerint egy ösnyomtatvány (Inc. 256, Marcus Tullius Cicero, Epistolae ad familiares, Velence, 1487, A. de Paltaszichis - korábban egybekötve egy XVI. századi Cicero, Epistolae ad familiares, Párizs, 1557, apud Audoëneum Parvum, kiadással, Ant. 4297) a könyvtár legrégebben, 1586-1589 között beszerzett és máig folyamatosan használt és megörzött kötete. Ez az egyik jogelőd könyvtárban, Turóc-Znióváralján (ma Kláštor pod Znievom, Szlovákia) már használt kolligátum a jezsuita oktatásban a XVI. századi kezdetek óta Európa-szerte használt tankönyvnek számított. Legkorábbi tulajdonosi bejegyzése: „Societatis Jesu inscriptus Catalogus - Collegium Turocensis”. Később Vágsellyén egy újabb tulajdonosi bejegyzést írtak a kötetbe: „An[no] 1600. Selliensis”, melyet az egyetemalapítást megelözően követett a „Tyrnaviensis 1632”. 
$\mathrm{Az}$ ismeretlen nagyszombati Szabó Ferenc városi polgárt egy ismertebb nevezetes személy követi újabb ajándékozóként, Partinger Gáspár, aki nagyszombati városi tanácstag volt, s öt ősnyomtatvány kötettel, Nicolaus de Lyra ötkötetes Biblia-kommentárjával gazdagította 1616-ban az állományt. ${ }^{16}$

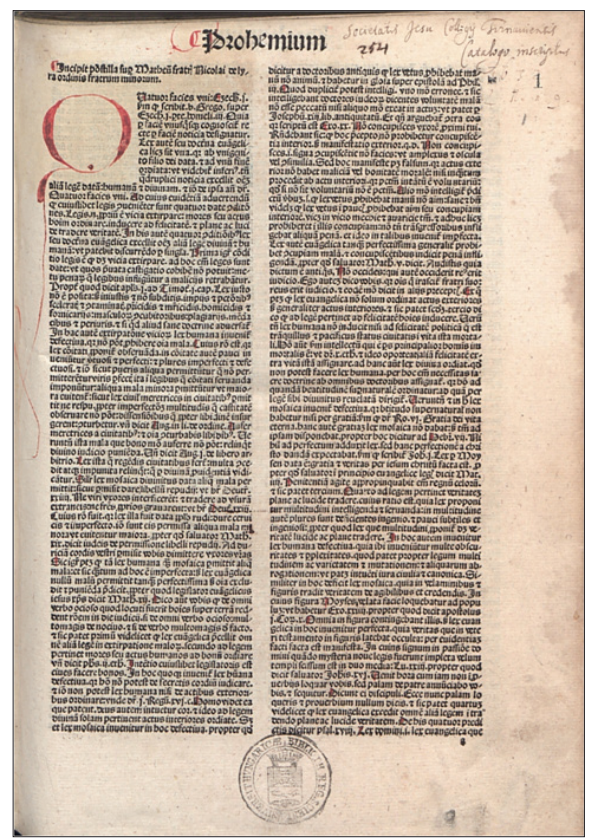

7. kép. Biblia, Nürnberg, 1485, 1r Inc274

Ezt az első hat ősnyomtatványt továbbiak követték a nagyszombati egyetem megalapításáig (1635). ${ }^{17} \mathrm{Az}$ egyetem megalapítása előtt a gyüjteménybe bekerült teológiai és egyházjogi ősnyomtatványok mellett matematikai munka (Claudius Ptolomaeus, Quadripartitum cum aliis tractatibus) éppúgy megtalálható, mint az 1633-ban beszerzett, a második magyarországi ősnyomdából kikerült Antoninus Florentinus Confessionaléja.

${ }^{16}$ Ennek a Biblia. Cum postillis Nicolai de Lyra [...] (Nürnberg, Anton Koberger, 1487) címú münek a címlapján első bejegyzésként az „Ex dono Dominij Caspari Partingeri Collegij Soc[ieta]tis Jesu Tyrnaviae 1616" szerepel, melyet a máig fennmaradt, legkorábbi nagyszombati kéziratos katalógusra történő utalás követ, az „Inscriptus Catalogo 1632. L[ittera] N. n[umero] 6. 7. 8. 9” formában.

${ }^{17}$ Közülük a legrégebben megjelent nyomtatvány Franciscus de Platea Opus restitutionum usurarum et excommunicationum (Padova, Leonardus Achates, 1473) címü munkája volt, melyet az első fennmaradt könyvtári katalógusban a „Francisci de Platea Opus restitutionum in folio corio rubro Paduae 1473” formában örökítettek meg. Jelenleg ebből a kiadásból a könyvtár nem öriz példányt, az egyetlen magyarországi példány a Magyar Tudományos Akadémia Könyvtárában található meg (jelzete ott: Inc. 518). Időben ezt követi Szent Ágoston De civitate Dei című művének két velencei kiadása (Gabriele di Pietro, 1475 - Inc. 25; Bonetus Locatellus, 1486/1487 - Inc. 221). 


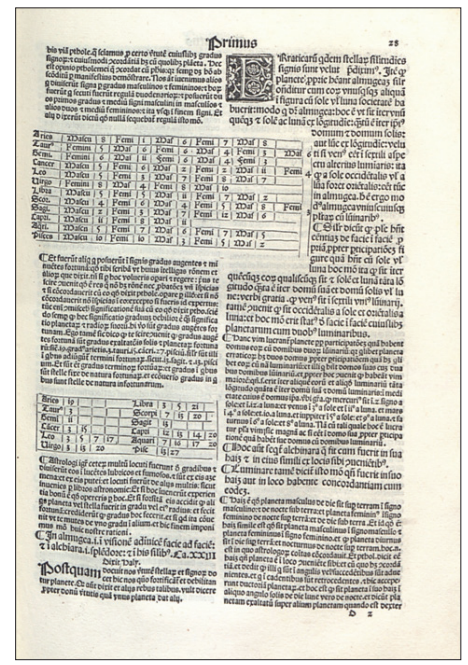

8. kép. Klaudios Ptolemaios, Quadripartitum, Venezia, 1493, 28r Inc 487

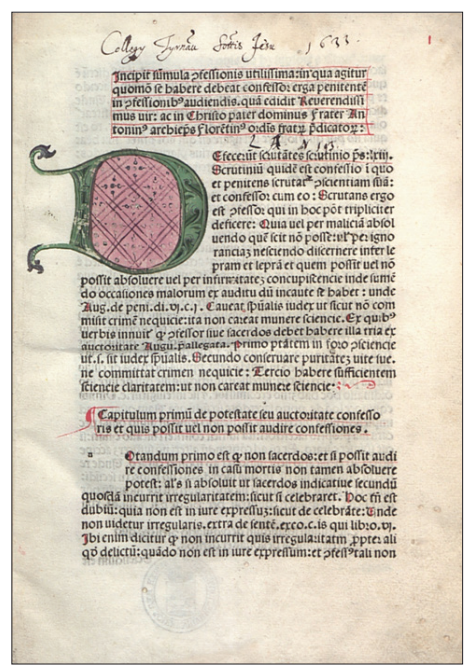

9. kép. Antoninus Florentinus, Confessionale, [In Hungaria, 1477], Ir Inc 46

Utóbbinak a tulajdonosi bejegyzése a címlapon „Collegij Tyrnau[iensis] So[cie] t[a]tis Jesu 1633. L[ittera] A. N[umero] 193," s e nevezetes példány mellett egy másik, variáns példányt is őriz a kiadványból a könyvtár. ${ }^{18}$

${ }^{18}$ Antoninus Florentinus firenzei érseknek e XV. század közepén készült műve gyóntatói segédkönyv, melynek több mint száz különböző ősnyomtatvány-kiadása ismert. Fitz József és Soltész Zoltánné kutatásai tették nyilvánvalóvá, hogy a fenti példányok és egy további, Gyöngyösön örzött példány a Magyarországon 1477-1480 között müködött második hazai ősnyomda terméke, s azt nem Nápolyban nyomtatták Matthias Moravus tipográfiájában. 


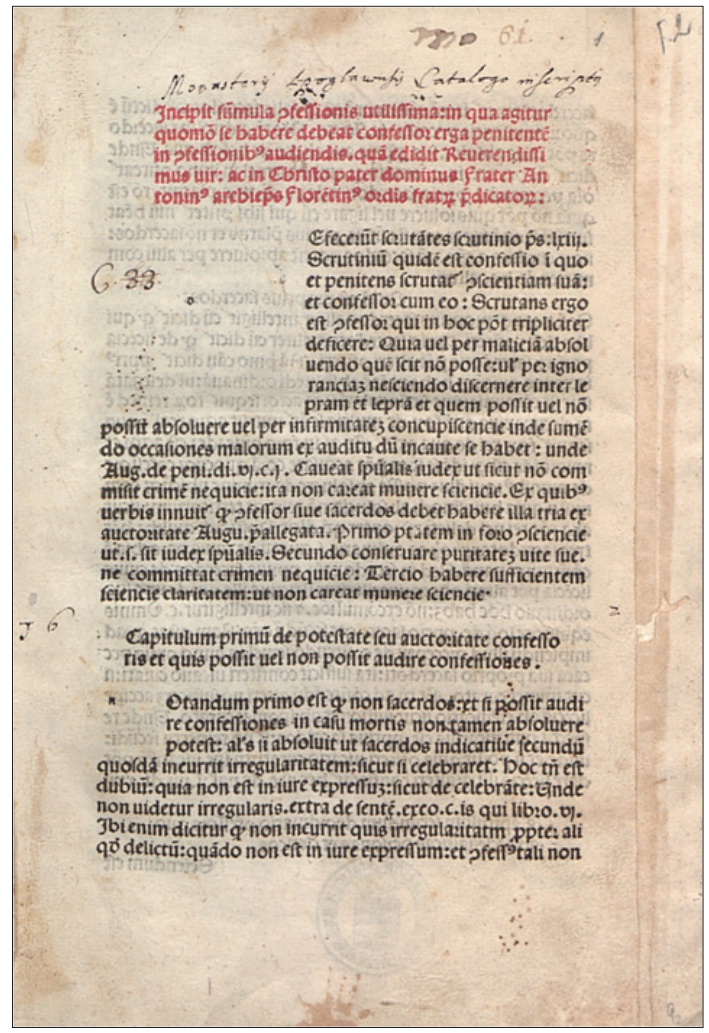

10. kép. Antoninus Florentinus, Confessionale, [In Hungaria, 1477], 1r Inc 45

1635 előtt összesen huszonhat ősnyomtatványt ôrzött a nagyszombati jezsuita könyvtár, melyek közül húsz ma is a gyüjtemény része. Valószínü, hogy két továbbit is őriz a könyvtár, de ezeknek időközben megsérült a tulajdonosi bejegyzése. Azaz az ősnyomtatványtár legrégebbi huszonhat kötetéből huszonkettőt közel 380 éve öriz a könyvtár.

A nagyszombati jezsuita egyetem megalapítását követően további ősnyomtatványokkal gyarapodott az állomány. ${ }^{19}$ Kiemelem közülük az 1681-ben beszerzett Euklidesz Elementa geometriát.

${ }^{19}$ 1637-ben Armandus de Bellovisu De declaratione difficilium terminorumát (Basel, 1491 - Inc. 418), 1690-ben Petrus Lombardus Sententiarum libri quatuor-ját (Nürnberg, Anton Koberger, 1491 - Inc. 424) és Michael de Dalen Casus brevies Decretaliumát (Strassburg, Georg Husner, 1493 - Inc. 470), 1692-ben Cassiodorus zsoltármagyarázatait (Cassiodorus Senator, Flavius Magnus Aurelius, Expositio Psalterii, Basel, Johann Amerbach, 1491 - Inc. 425) szerezték be. Plinius Historia naturalisának 1491-ben megjelent velencei kiadása (Inc. 432) a nagyszombati jezsuita kollégium által megszervezett egyik Mária kongregáció könyvtárából került a jezsuita könyvtárba (az ajándékozó bejegyzés szerint Szomori Mátyás adta a kötetet a kongregációnak 1655-ben: „Sodalitatis B[eatae] V[irginis] Visitantis in Collegio Soc[ietatis] Jesu Tyrnav[iensis] 1655 dedit Dominus Mathias Szomori”). 


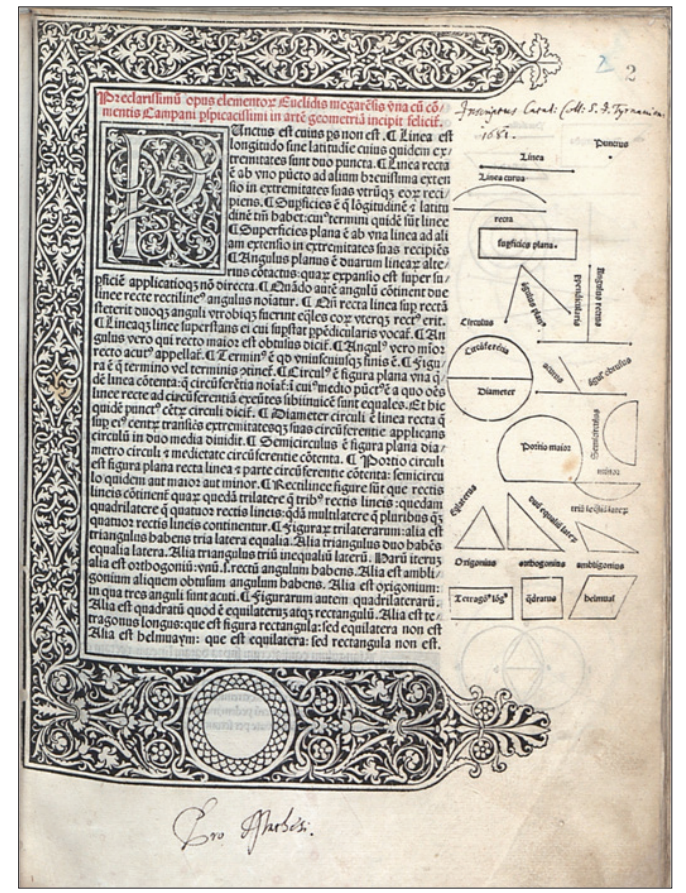

11. kép. Euklides, Elementa geometria, Venezia, 1482, 2r Inc115

A jezsuita rend feloszlatásáig (1773) folyamatosan gazdagodott a könyvtár állománya ősnyomtatványokkal, ezek kivétel nélkül használati könyvként és nem célzottan megvásárolt ritkaságként kerültek a gyüjteménybe. Az ösnyomtatványtár legjelentősebb állomány-növekedése Mária Terézia, majd II. József szerzetesrendeket feloszlató rendeleteinek köszönhető. A feloszlatott rendi könyvtárakból az uralkodó a bécsi udvari könyvtár elsőbbségének biztosítása után válogatási jogot adott a volt nagyszombati jezsuita egyetem könyvtárának államosítása után Budára, majd Pestre költöztetett egyetemi könyvtárnak. A könyvtár a Magyarországon használt ősnyomtatványok jelentős részének lett a gyüjtőhelye, több ritkaság is ezen az úton került be a könyvtári állományba. ${ }^{20} \mathrm{Az}$ ősnyomtatványok állományadatát a XVIII. század utolsó negyede végén csak megközelítően lehet megbecsülni. Vértesy Miklós kutatásai alapján tudjuk, hogy a rendelkezésre álló források közül a kötetekben ma is megtalálható tulajdonosi bejegyzések alapján a nagyszombati volt jezsuita könyvtári ősnyomtatványokon kívül 223 ősnyomtatvány egykori őrzőhelye volt jezsuita gyüjtemény. Ezek megoszlása a proveniencia szerint a következő.

${ }^{20}$ Ilyen például a Diurnale Argentinense (Basel, Michael Wenssler, circa 1491 - Inc. 830), melyből a Gesamtkatalog der Wiegendrucke mindössze öt példányt tart számon, s ezek között a budapesti Egyetemi Könyvtár példánya variáns példány. 


\begin{tabular}{|l|c|}
\hline \multicolumn{1}{|c|}{ Hely } & Kötetek száma \\
\hline Besztercebánya & 26 \\
\hline Eperjes & 15 \\
\hline Fiume & 12 \\
\hline Komárom & 10 \\
\hline Lőcse & 1 \\
\hline Pozsony & 87 \\
\hline Selmecbánya & 2 \\
\hline Sopron & 28 \\
\hline Szakolca & 3 \\
\hline Szatmár & 2 \\
\hline Szepes & 5 \\
\hline Trencsén & 4 \\
\hline Turóc & 3 \\
\hline Zsolna & 2 \\
\hline Bécs, Pazmaneum & 9 \\
\hline Egri egyházmegye bécsi & 11 \\
S. J. papnevelde & 1 \\
\hline Krems & 2 \\
\hline Triest & \\
\hline
\end{tabular}

A táblázatból nyilvánvaló, hogy a pozsonyi, a soproni és a besztercebányai jezsuita könyvtárakból került a legtöbb ősnyomtatvány az államosított nagyszombati egyetem könyvtárába. A jelentős számú pozsonyi gyarapodás oka elsősorban abban kereshető, hogy e jezsuita könyvtár örizte Mossóczi Zakariás nyitrai püspök XVI. századi gazdag magánkönyvtárának jelentős részét. ${ }^{21}$ Egy másik Vértesy által számba vett forrás Pray György Index rarioruma (I-II. kötet, Buda, 1780-1781). Pray összesen 179 ősnyomtatványt vett be munkájába, közülük 88 kötetben található egykori jezsuita tulajdonosi bejegyzés. Ha e két, eltérő forrásból származó adathoz becslés alapján (30-40 kötet) hozzáadjuk a Pray által kihagyott ősnyomtatványokat, illetve a tulajdonosi bejegyzést nem tartalmazó egykori jezsuita könyvtárakban őrzött XV. századi nyomtatványokat, az állományt 350 kötetre lehet becsülni.

A II. József által elrendelt rendfeloszlatások (1782-1786/88) következtében a feloszlatott 134 férfi és 6 női rendház könyvtárának állománya állami tulajdonba került. Vértesy András áttekintette a gyüjteménybe ekkor bekerült

${ }^{21}$ Ismeretes, hogy Mossóczi 1587-ben sógorára, Kecskés Andrásra hagyta könyvtárát, akitől Kecskés János nagyszombati kanonokhoz került. Kecskés János saját könyvgyüuteményével együtt a pozsonyi jezsuitáknak ajándékozta el a Mossóczi-féle könyveket. 
ősnyomtatványok utolsó tulajdonosait, s megállapította, hogy a bejegyzések és a beragasztott exlibris-eket figyelembe véve az ősnyomtatványok a következő rendektől származnak. ${ }^{22}$

\begin{tabular}{|l|c|}
\hline Szerzetesrend megnevezése & Ősnyomtatványok száma /kötet \\
\hline pálos & 208 \\
\hline minorita + ferences & 23 \\
\hline trinitárius & 11 \\
\hline szervita & 12 \\
\hline premontrei & 6 \\
\hline karmelita & 2 \\
\hline bencés & 4 \\
\hline
\end{tabular}

Teljes egészében egyedül a pálos rend könyvállományából származó ősnyomtatványok találhatók meg a könyvtárban (208 kötet). Ezek egykori rendházankénti megoszlása - szintén Vértesy András nyomán - a következö.

\begin{tabular}{|l|c|}
\hline Pálos rendház & Ősnyomtatványok száma /kötet \\
\hline Csáktornya & 25 \\
\hline Felsőelefánt & 24 \\
\hline Lepoglava & 49 \\
\hline Máriavölgy & 20 \\
\hline Nagyszombat & 8 \\
\hline Novi & 11 \\
\hline Pest & 31 \\
\hline Remete & 11 \\
\hline Többi, kisebb rendházból összesen & 29 \\
\hline
\end{tabular}

Az ősnyomtatványok korábbi tulajdonosainak figyelembevételével megrajzolhatóvá válik minden egyes, a gyüjteményben megőrzött ősnyomtatvány története.

A II. József kori abolició után a könyvtár ősnyomtatványainak száma becslés alapján - mintegy hatszáz kötet lehetett. Ez a mennyiség és a kötetek által képviselt minőség (a ritka és unikum példányok révén) egyedülálló volt az országban. Így például a legértékesebb, 1470 előtt készült ősnyomtatványok száma négy (Inc. 789, 790, 867, 872). II. József 1785-ben rendeletet adott ki

${ }^{22}$ A táblázatba foglalt adatok az egykori valóságot nem minden részletükben tükrözik, mivel egyrészt léteznek a kötetekben úgynevezett ,rejtett” tulajdonosi bejegyzések is, másrészt például a pannonhalmi bencés apátságból beszállított ősnyomtatványok a könyvtárból számba vett négy kötet kivételével visszakerültek Pannonhalmára. Az adatokat az is torzítja, hogy egyes szerzetesrendek nem minden feloszlatott rendházából kerültek be az Egyetemi Könyvtárba az ősnyomtatványok. 
az abolició révén bekerült másod- és többes példányok értékesítésére. ${ }^{23}$ Ezeken az árveréseken négy ősnyomtatványt kínált megvásárlásra a könyvtár, ${ }^{24}$ közülük egy, Jacobus Sprenger és Henricus Institoris híres, a boszorkányperek lefolytatói számára írt kézikönyvének, a Malleus maleficarum (Nürnberg, Anton Koberger, 1496, H *9246) többes példánya biztosan elkelt, harminc krajcárért. ${ }^{25}$

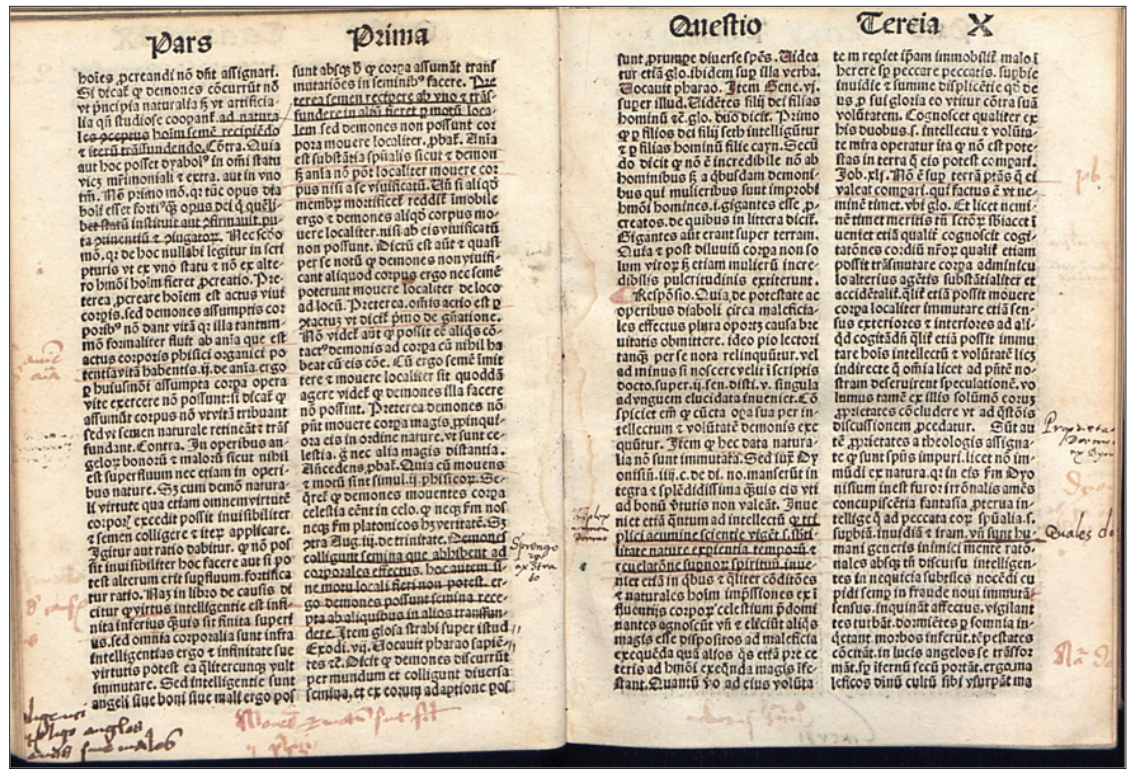

12. kép. Malleus maleficarum, Nürnberg, 1496, Inc591

A könyvtár ősnyomtatványai csak 1875 után kaptak egyedi jelzetet, amikor befejeződött az átköltözés a mai épületbe. A XV. századi nyomtatványok leválasztását az állományból, önálló gyüjteménnyé rendezését és katalogizálását Kudora

${ }^{23}$ A rendelet végrehajtása során 1787-1797 között hét árverést rendezett az Egyetemi Könyvtár és összesen 20.031 könyvet kínált eladásra, mely a további többes példányok figyelembevételével mintegy 25.000 kötet lehetett. Az árverések nyomtatott katalógusai (Catalogus librorum, gui in Bibliotheca Universitatis Pestiensis publicae auctioni exponentur, [hét füzet], Pest, 1778-1797) a könyvtár történetének becses forrásai, kutatásuk még éppen csak elkezdődött.

${ }^{24}$ Hain-számokkal kifejezve ezek a következők: H 3118, H 1249, H 5388, H 9246.

${ }^{25}$ A későbbi időszakban - annak ellenére, hogy 1802-ben I. Ferenc rendeletére a szerzetesrendek részleges visszaállítása megtörtént, s e rendelet végrehajtási utasítása kötelezte az Egyetemi Könyvtárat a biztosan megállapítható korábbi tulajdonjog alapján a könyvek visszaállított rendeknek történő visszaadására - még két árverést $(1806,1826)$ tartottak a könyvtár állományából. Az 1806-ban eladásra kijelölt ősnyomtatványt (H 8562), Szent Jeromos leveleinek 1495. évi nürnbergi kiadását nem vásárolták meg, a müből jelenleg két példányt őriz a könyvtár (Inc 547, 548). 1826-ban összesen tizenkét ősnyomtatványt adtak el, melyekből tizenegyet megvásároltak. Utóbbiakat a híres gyüjtő Jankovich Miklós (három kötet), a könyvtár első őre, Veszerle József (négy kötet) és J. B. Redl (négy kötet) szerezte meg. 
Károly végezte el 1881-ig. ${ }^{26}$ 1901-ben történt meg a tár újrarendezése. Dedek Crescens Lajos 1-960 sorszámmal jelzetelte a gyüjteményt (953 mü $=972$ kötet), melyben hét szám üresen maradt. ${ }^{27}$ A nyomdakész katalógust 1907 óta szerette volna kiadatni Ferenczy Zoltán igazgató, ezt azonban meghiúsította az I. világháború, s a kézirata ma lappang. A tár állománya 1945-ig további mintegy 110 kötettel gyarapodott, ezek jelentősebb része a már meglévő könyvtári állományból mint datálatlan (keltezetlen) nyomtatvány került elő. Az 1946 utáni beszerzésekkel együtt az 1949. évi revízió szerint a tár állománya 1089 kötet volt. Az 1949-1964 között vásárolt tizenhárom ősnyomtatvány a vétellel történő gyarapodások között jelentősnek számít. Gyarapodott az ősnyomtatványok száma az Országos Könyvtárügyi Tanács állománygyarapítási és könyvforgalmi szakbizottságának 1960. VI. 30-án hozott döntése alapján is, mely szerint az ösnyomtatványok szétosztásánál elsőként a nemzeti könyvtár, másodikként az Egyetemi Könyvtár igényelhet az 1952-1954 között állami tulajdonba vett 1500 előtt készült nyomtatványokból. E döntés alapján tizenegy kötettel bővült a tár 1962. decemberig. A gyarapodás lényegében azóta is folyamatos, bár nagyon lassú a beszerzés anyagi nehézségei miatt.

A könyvtár jelenleg az 1200-nál több bibliográfiai egységet őrző ősnyomtatványával Magyarország harmadik legnagyobb incunabulum-gyüjteménye. Több olyan kötettel bír, amely ezeknek a kiadásoknak az egyetlen ismert példánya. ${ }^{28}$ Kiemelkedő jelentőségüek azok az ősnyomtatványok - így például a

${ }^{26}$ Tervbe vették e katalógus nyomtatott megjelentetését, ami azonban kétszer is elmaradt az újabb ősnyomtatványok elökerülése miatt.

${ }^{27}$ A katalógus alapján a XVIII. század vége óta jelentősen tovább bővült az állomány, összesen 972 ősnyomtatvány kötetet tartottak ekkor számon, melyhez hozzá kell számolni még kb. 40 datálatlan, később a gyüjteménybe sorolt kötetet.

${ }^{28} \mathrm{Az}$ ösnyomtatványok jelzete - más hazai ősnyomtatvány-gyüjteményekhez hasonlóan - az 'Inc' rövidítésböl és numerus currens arab számból áll. Az ösnyomtatványok úgynevezett rövid címleírása ma már elektronikus formában is elérhető, s a könyvtár tervbe vette a könyvészeti leírások bővített formátumú, a kötetek egyéni jellegzetességeire is figyelö leírások elkészítését. Utóbbit mindez ideig erőteljesen nehezítette egy, a tár egészét jellemző sajátosság, a kötetek hosszú időszakot átívelő intenzív használtsága miatt a hiányos példányok sokasága. A nagyon sok esetben, szinte általában hiányzó első és utolsó levelek, sérült könyvtestek, töredékesen fennmaradt lapok éppúgy lelassítják az azonosítást, mint a bővített feldolgozást. Ugyanakkor a köteteknek ez a sajátos állapota nem véletlenszerü, hanem a korszakokon át tartó folyamatos, általában oktatási vagy tanulási tevékenység következménye. Ez az utóbbi körülmény ugyanakkor különösen becsessé teszi a gyüjteményt, mivel az egyes kötetek nem csupán könyv- és könyvtártörténeti jelentőségüek, hanem oktatás- és müvelődéstörténeti sajátosságokat is hordoznak. E sajátosságok jelentős része a gyüjteménybe kerülés (proveniencia) tényével kiegészítve új kontextusba helyezik a tár egészét, s együttes megközelítésük országos történettudományi, irodalomtörténeti és pedagógia-történeti érdeklődésre tarthat számot. A gyüjtemény történetét - mint arról már esett szó - Vértesy Miklós foglalta össze tizenhét oldalon 1964-ben (Az Egyetemi Könyvtár ösnyomtatvány-gyüjteményének története $=$ Az Egyetemi Könyvtár Évkönyvei 2 (1964) 109-126.). A tár egészéről azóta nem készült újabb, mértékadó szaktudományos publikáció. Legutóbb az Egyetemi Könyvtár 450 éves 
Chronica Hungarorum (Buda, 1473, Andreas Hess; Inc. 10) itt örzött, végig rubrikált példánya -, melyek a kutatás tanúsága szerint megjelenésük óta magyarországi tulajdonban vannak. ${ }^{29}$ Fontos megemlíteni az egykor a budai királyi kápolna (Capella Regis) könyvtárában őrzött Aurelius Augustinus, De Civitate Dei (Roma, 1474, U. Han - S. N. Chardella; Inc. 16) országos unikum példányt is. Egy Velencében 1475-ben nyomtatott Biblia a könyvtárban őrzött legkorábbi nyomtatott Biblia, melyet 1476-ban Budán vásárolt meg egy Ágoston nevủ zágrábi domonkos szerzetes.

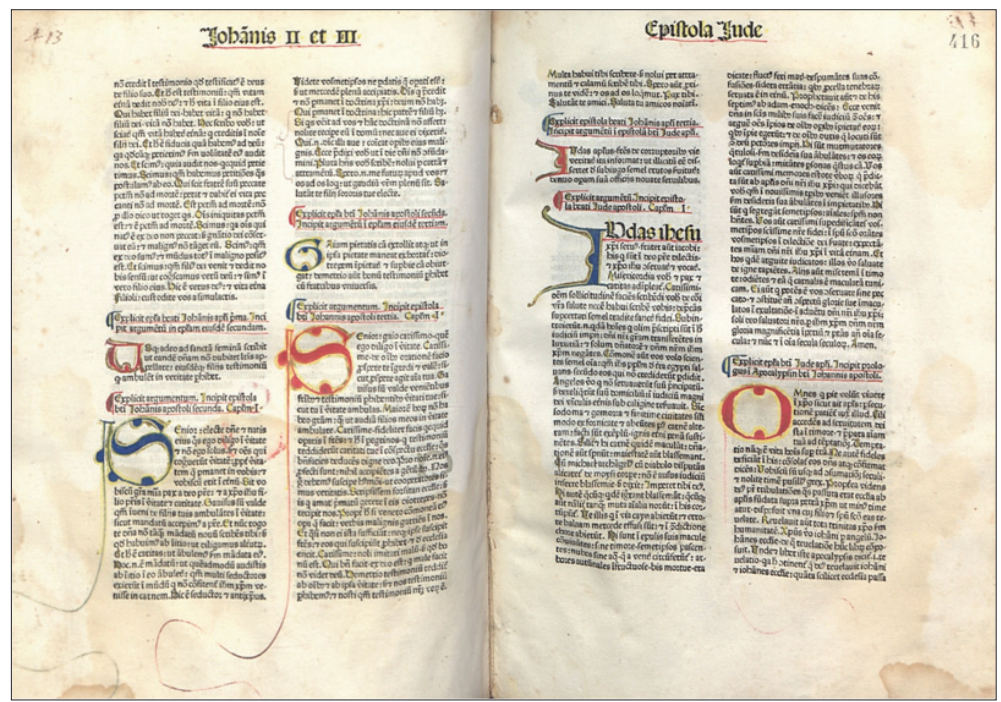

13. kép. A könyvtár legrégebbi nyomtatott Bibliája (Venezia, 1475), 415v-416r, Inc28

Egy másik ősnyomtatvány Bibliát egykor valószínüleg Istvánffy Miklós könyvtárában őriztek, akihez a kötet egy XVIII. századi legenda szerint a Bibliotheca Corviniána állományából került. ${ }^{30}$

múltjába helyezett kétnyelvű művelődéstörténeti bemutatás készült a könyvtár ősnyomtatványairól (Knapp Éva: Ösnyomtatvány-gyüjtemény - Collection of Incunabula. = Knapp Éva - Szögi László, Az Eötvös Loránd Tudományegyetem Egyetemi Könyvtára - University Library of Eötvös Loránd University, Budapest, ELTE Egyetemi Könyvtár, 2012, 94-111). A tár egyes példányairól folyamatosan jelennek meg tudományos szaktanulmányok (az egyik legutóbbi publikáció: Anna Tüskés, A Copy by Israhel van Meckenem of the Luke the Evangelist in Circle Engraving by Master E. S. in the University Library of Budapest $=$ Arbeitskreis Bild Druck Papier Tagungsband Modena 2010, Hrsg. Wolfgang Brückner, Konrad Vanja, Detlef Lorenz, Alberto Milano, Sigrid Nagy, Münster New York - München - Berlin, Waxmann, 2011, 148-153).

${ }^{29}$ A Chronica Hungarorum e példányát a könyvtár múzeumi tárgyakért kapta cserébe 1875ben a mai Országos Széchényi Könyvtár elődjétől, a Nemzeti Múzeum Könyvtárától.

${ }^{30}$ A példákat folytatva, Antoninus Florentinus, Confessionaléjának ([In Hungaria] 1477 [typ. Confessionalis]; Inc. 46) 'A' változatát1633 óta, azaz az egyetem megalapítása elötti időtől folyamatosan örzi a könyvtár. 


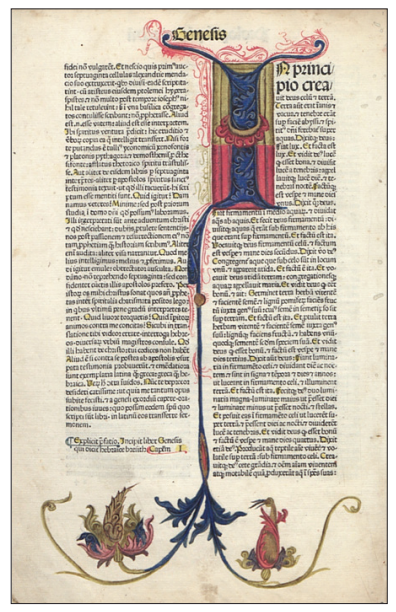

14. kép. Istvánffy Miklós történetíró Bibliája (Venezia, 1476), valószínűleg a Bibliotheca Corvinianából származik. Inc1016 3v

A kötetek egykori tulajdonosi köre nagyon széles, neves humanisták, így például Váradi Péter, idősebb Henckel János (Inc. 179), Mosóczy Zakariás (Inc. 550) éppúgy megtalálhatók közöttük, mint nevezetes magyarországi szerzetesrendi könyvtár (Lövöld = Városlöd karthauzi kolostor, Inc. 139), vagy szerzetes (Hadnagy Bálint budaszentlőrinci pálos szerzetes és hitszónok (1460/70 k. - 1537), Inc. 372³1).

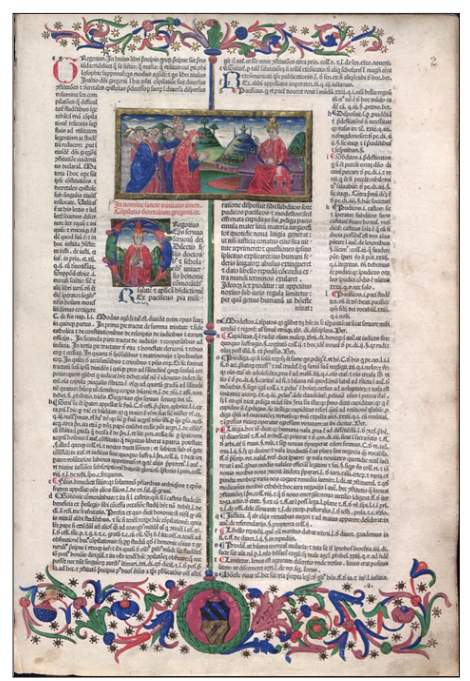

15. kép. A neves humanista Váradi Péter Decretalis-a (Venezia, 1479), 2r Inc65

${ }^{31}$ Az egykor Hadnagy Bálint által használt kötetet később, 1628-ban a lepoglavai pálos kolostor könyvtárában örizték, majd a II. József kori szerzetesrend-feloszlatások következtében szállították be a mai könyvtár jogelőd könyvtárába. 
A tár tervbe vett elektronikus feltárásának eredményeként fény derülhet a történeti könyvtárak és tulajdonosaik, valamint használóik összetett kapcsolatrendszerére, s ez messzemenően gazdagíthatja a világi és egyházi tulajdonosok részletekbe menő kapcsolatának „müködési” formáit, mechanizmusát.

\section{Rezümé}

A dolgozat bemutatja az ELTE Egyetemi Könyvtár ősnyomtatványait, mely az ország harmadik legjelentösebb Ösnyomtatvány-gyüjteménye (Incunabula). A gyüjtemény a könyvtár történetének kezdetétől folyamatosan gyarapodott, törzsgyüjteménnyé alakítása és máig érvényes összerendezése 1879-1882 között zajlott. Az állomány számba vétele megtalálható a magyarországi közgyüjtemények országos ősnyomtatvány-állományát feltáró nyomtatott katalógusban (Catalogus incunabulorum quae in bibliothecis publicis Hungariae asservantur, ediderunt Géza Sajó, Erzsébet Soltész, I-II, Budapestini 1970 Akadémiai Kiadó). A gyüjtemény a könyvtár egyetlen olyan tára, mely hungaricum nyomtatványokat is őriz, azaz 1500. december 31-e előtt Magyarországon, illetve magyar szerzőktől megjelent múveket. A tár a felállítását követő száz évben mintegy száz művel gyarapodott. Ezek nem elsősorban vásárlások útján, hanem a könyvtár raktáraiból, átsorolással kerültek a gyüjteménybe.

\section{The Incunable Collection of the ELTE University Library}

The paper presents the incunable collection of the ELTE University Library, which is the third largest one in the country. The collection has been continuously augmented since the beginnings of the history of the library, its even now existing structure had been formed between 1879 and 1882 . The apiece survey of the collection can be found in the printed catalogue that reviews and describes all the incunable collections that are in the possession of public libraries, archives and museums in Hungary. (Catalogus incunabulorum quae in bibliothecis publicis Hungariae asservantur, ediderunt Géza Sajó, Erzsébet Soltész, I-II, Budapestini 1970 Akadémiai Kiadó). This is the only collection of the library that includes Hungarica prints, namely works that were printed before $31^{\text {st }}$ December 1500, and they originate either from Hungary or they were written by Hungarian author. The century that followed the organization of the collection had augmented it with ca. a hundred works. Not the purchasing was the cause of this accession, but rather finding items in other storages of the library and relocating, recategorizing them.

KNAPP ÉVA

fötanácsos, tudományos ügyek referense ELTE Eötvös Loránd Tudományegyetem Egyetemi Könyvtár 